\title{
MEDIA CONTENT ANALYSIS ON SCHOOL VIOLENCE AND AGGRESSION IN BULGARIA
}

\author{
Vera Zaharieva \\ National Sports Academy "Vassil Levski" (Bulgaria)
}

\begin{abstract}
This research offers a review of the online news content in Bulgaria, related to school aggression, violence, and sports initiatives tackling those behavioral problems. The aim is to provide an understanding of the phenomenon and the societal attitude towards its dimensions and possible solutions through sport. A media content analysis of online articles, dated January 2019 - April 2020, was used as a research methodology. Thirty-three articles on aggression and violence in school were reviewed, based on their frequency, timeline, place of publication, topics, and spokesperson. For the same time period, sixteen articles related to dealing with aggression through sport were reported. The results show that most of the media content on violence and aggression among students was related to raw statistical data and reports of cases. A relatively small section in the news was dedicated to opinion articles. It was observed that those who witness cases of aggression do not understand the seriousness of the situation and see it as entertainment. As a result, a major part of the video content, related to aggression, is being uploaded on the Internet by students and parents. However, the public focus is mainly shifted towards the school authorities and the figure of the teacher. At the same time, aggression in schools is spread among all students. It has a constant value and is provoked by numerous factors. On the contrary, initiatives and events aiming to disseminate information and to reduce aggression through sport were organized in many Bulgarian cities by nonprofit organizations, municipalities, and schools. The majority of events were organized as a part of European or national projects. It is suggested a more centralized national approach towards reducing aggression through different sports activities in school.
\end{abstract}

Keywords: school; students; teachers; sport; aggression; media

\section{Introduction}

Most of us naturally perceive the school environment as a secure place, with strict rules and discipline where nobody can get hurt because of the constant teacher supervision. A place where we all go to learn, create lifelong friendships, and apply what we have learned in our everyday life. However, gathering many children with different backgrounds and behavior in one place is often a prerequisite for a 
clash of different mindsets, perceptions, habits, etc., causing cases of violence and aggression between students.

As an important part of school climate, safety is being measured by analyzing various incidents of school violence, bullying, crime, and perception of safety (Hamlin \& Li 2020; Ripski \& Gregory 2009). High levels of violence and aggression might cause school absenteeism, which is being often associated with lower academic achievement (Gottfried 2009), school dropout (Neild \& Balfanz 2006), and criminal activity (Spencer 2009). Modern societies have struggled for decades to find solutions to this social phenomenon

In the school context, sports activities can positively contribute in lowering the levels of aggression between peers. In general, participation in sports activities promotes a healthy and active lifestyle, gives an opportunity to interact with peers, promotes values such as empathy, fair play, and conflict-solving skills. Many scholars have proven the positive impact of sports activities on crime prevention, bringing forward the social-change mode by shifting the focus towards meaningful concepts (Ekholm 2013). In addition, sports activities have an indirect effect on reducing peer aggression and aggression toward oneself through the creation of a sustainable social environment (Lee \& Lim 2019). Sports values promote discipline, teamwork, and cooperation. According to sociological research, 57\% of children aged between 5 and 13 participate in sports on a regular basis (BTV 2020).

\section{Aim of the study}

Many people called school aggression a "world pandemic" many years before the COVID-19 pandemic hit the globe. In 2017, the Institute for Population and Human Studies in cooperation with UNICEF found that Bulgaria is among the top 10 countries, affected by the problem of "school bullying" (UNICEF 2018). But, does this mean that school aggression is widely presented in the media context? How is this problem articulated and what messages are being sent to the general public? Is there a way out of this behavioral crisis and are there social initiatives, involving sports activities as a counterpoint to aggression?

This media content analysis aims to review and present the online media publications, related to school violence, aggression, and sports initiatives, aiming to tackle those behavioral problems in Bulgaria. The detailed review of the news segment provides a deep understanding of the current phenomenon and the societal attitudes towards it. Such an analysis gives not only raw data on the cases of aggression but also highlights the importance of the problem for our society. The frequency of articles on the broad topic of "sport as a tool against aggression" shows the publicity of such events and their dissemination effectiveness. The present study is focusing on the different types of articles, their frequency and coverage, the spokespersons and engaged figures, and all the important details aiming to give to the reader a good understanding of the problem, its media coverage, and the frequency of events. 


\section{Methodology}

\section{Period of the collected news material}

The used research methodology is a media content analysis of online articles, dated January 2019 - April 2020. Thirty-three articles on aggression and violence in school were reviewed, based on their frequency, timeline, place of publication, topics, and spokesperson. Four of them can be classified as opinion pieces (op-eds, columns, or editorials) and the other twenty-nine are news (straightforward articles, reporting the latest events). The number of articles, published on the Internet from January 2019 to December 2019 using the keywords "aggression in schools" was 2310. The number of news articles only for the period between 01 January 2020 and 12 May 2020 using the same keywords is 2370 . For the same time period, sixteen articles related to dealing with aggression through sports activities were reported and reviewed for the purposes of the present study.

\section{Frequency and timeline}

This study traced the frequency of publications for the reviewed period and analyzed the timeline of video news segments in the major television channels, regarding the importance of the respective event.

\section{Places of publication}

The articles were divided and reviewed, based on their places of publication television channels, online newspapers, and online informational websites.

\section{Topics of the collected materials}

The articles were divided into Good practices, Opinion articles, News, and Statistics. The aim of such a division is provoked by the need to review and group each publication into a different media material which is sending different messages to the public.

\section{What messages are being sent and by whom?}

The present study examines who is the spokesperson in each of the reviewed media materials and what types of messages does the society hear from the speaker. This not only shows the active speakers and voices of these events but also presents the views of the journalists on the topic and creates an attitude towards the phenomenon and the actors, involved in it - teachers, parents, and students.

\section{Results and analysis \\ Types of collected media articles \\ Good practices}

In total, there are three reported good practices, showing a positive example of how to handle aggressive behavior. One article tells the story about a good practice in dealing with aggression, implemented by a school in the city of Velingrad (NOVA TV 2019). Another one presents the initiative of the Varna Free University which is helping with resources to more than 300 schools throughout the country, with more than 20 courses for prevention of aggression, aimed at teachers, parents, and students 
(Trud.bg 2020). The third reported good practice is about two athletes teaching children how to cope with aggression in a non-aggressive way (24 Chasa.bg 2020).

\section{Opinion articles}

One of the four opinion articles, published in an online newspaper, examines the problems and good practices from other countries, focusing on Japan, the USA, and Great Britain (24 Chasa 2020). Another opinion article describes the complex relations between family, school staff, and students. It tells the story of a bully and his family and traces the reasons for aggressive behavior by giving statistical data from different opinion researches (News.bg 2020). Next comes an article by Mr. Pandin - a Bulgarian psychologist examining the existing mechanisms against school aggression. The main thesis of Mr. Pandin is based on the lack of implication of the existing prevention mechanisms in dealing with aggression. He is stressing that the school system is only active in terms of post-event activities, but does not apply the written strategies for prevention (Off News 2020). The last opinion piece is a video, aired on one of the main television channels, provoked by a school accident in the city of Kubrat. According to the school principal, the uploading of a video on the Internet of an incident or a fight between two students provokes even more aggression. She calls for cooperation between institutions and for the prosecution of those people, who upload videos of students with violent content (BTV 2020).

\section{News}

In the reviewed report cases of school violence and aggression are prevailing those, where students only are involved, but there are also reported cases of aggressive behavior on behalf of teachers ( 2 articles) and parents ( 3 articles). In both cases of aggressive behavior on behalf of the teachers, they were accused of violent methods in dealing with a fight between students. Again, one of the observers took a video and published it on the Internet. (Darik news 2019). Two articles report student aggression against teachers. In both cases, students made a video of the event, which was uploaded on the Internet and was aired on the primetime news segment (NOVA TV2019).

Yet another worrying trend is the aggression from parents of students towards other students. Three of the reviewed news articles report cases of parents who acted violently. All articles describe a previous conflict between students, which led to parental intervention. Statistics show a high percentage of domestic violence in Bulgaria (Center for the Study of Democracy 2020), which inevitably provokes child aggression.

\section{Statistics}

Five articles give statistical data of bullied children in schools and compare the cases of physical aggression to other European countries and to previous years. An 
article reports that over 9000 children have committed a crime in 2019. It points out that the actual number is much higher, because of the unreported cases (Bulgaria On Air 2020).

There is almost no change in the level of aggression among children. The difference between the academic years 2016/2017, and 2017/2018 is only 10 cases - 433 to 423. According to officials from the Ministry of Education, there are several factors for this trend - social environment, graphic media content, as well as a large number of students in some schools. The high percentage of children growing up in a deteriorating social environment - with one parent, in situations of parental conflict and of parents who work abroad, creates preconditions for the children to try to solve various problems through aggression. The second factor is the media content. Not only what they watch on the television, but also on the Internet (Actualno.com 2019).

Worrying data shows that many children go to school carrying boxes, knives, and electric batons. Another article reveals that the interest from students in buying a knife or a box is very high, reported by shop-owners. Although it's illegal to sell to persons under 18 years of age, still they manage to find a way to buy them (Darik news 2019). The necessity of school psychologists in every school is being widely discussed by the authorities and the non-governmental sector over the past few years with yet no centralized decision.

According to statistics, provided by the Ministry of education, the registered cases of aggression against teachers have almost doubled. In 2015/2016 they were 220 , in 2017/2018 they were 391, and for the 2018/2019 academic year, they became 476 (National Network for Children, 2019). Those worrying numbers indicate, on one hand, the raising aggression among children, and, on the other, the inability of teachers to cope with a situation of violence and aggression.

A television channel aired in their news segment information from a conducted research, according to which $80 \%$ of children in school have been victims of aggression in the classroom. The questionnaire was done among nearly 200 teenagers, aged 13 to 18 years. In $65 \%$ of the cases, girls are the ones acting aggressively. Boys usually use violence in order to demonstrate strength (Nova TV 2019).

\section{Sports initiatives, tackling aggressive student behavior}

All sports initiatives, present in the media for the reviewed period, can be divided into three categories - projects, personal initiatives, and those of schools and municipalities. Such events were reported online throughout the whole time period of the present research. The variety of organizers and types of initiatives (videoclips, sports events, methodologies, information campaigns, etc.) shows an innovative approach and orientation towards effectiveness. Some initiatives covered the whole country, others were organized in small and big cities. Focusing 
on lowering the levels of aggression through sports activities, those events targeted different age groups of children - from pre-school to high-school students.

One of the good examples comes from Yordan Yovchev, the first Bulgarian world champion in gymnastics. As a "star teacher" he inspired the students from a Bulgarian school in Sofia to go out and play. He gave a personal example and urged the children to avoid aggression (NOVA TV 2019). Another example is the visit of the European kickbox champion Dimitur Penchev, who visited the Primary school Hristo Botev in the city of Pleven (Hristobotevpl.info 2019). This active engagement of public figures against aggression and violence represents an effective approach by shifting the focus towards ethics, cooperation, and respect.

The Bulgarian institutions and the non-governmental sector realized the need to disseminate good practices through sports participation. As an effective way to tackle this issue, sport comes to the forefront in the fight against aggression on different levels - national, local, and regional.

\section{Discussion}

\section{Frequency and timeline of the publications}

Based on the findings, one can conclude that the frequency of such events is mostly during the school year (September to June). However, the reported publications were throughout the whole researched period. This shows that aggression has no boundaries and has no limitations. The phenomenon is widely spread and covers all cities in Bulgaria.

As per the media reporting itself, the news' segments that the reviewed articles were aired are mostly during the first half of broadcasting - meaning that they are given attention and are considered important news for the viewers. News with such content is usually posted on the main pages of newspapers, on the top of the online editions, and they usually attract the attention of the public. Cases of school aggression often reach the public through videos, uploaded on the internet or, by signals from the parents of the victims.

\section{What messages are being sent and by whom?}

In most of the articles, the one who is interviewed is a parent of a child, a victim of school aggression. In each case, principals and/or deputy principals are asked for explanations and post-actions, taken after a violent event at school. Most of the measures taken in such a situation conclude in the expulsion of the aggressive student from the school. The parents of the victims usually blame the school authorities for a lack of preventive measures against the aggressors. It is noticeable that in 2019 the most interviewed decision-makers were the Minister of Education and the Deputy Minister of Education.

What is missing out of the news section is concerning the burden of the teacher - how to deal with aggressive students from a different social background; what can be done to help teachers to educate them on the basic principles and psychological 
aspects of aggression; how to help students through programs and sports activities, etc. The news content consists mostly of the brutal and picturesque description of a violent event. Which up to one point is an understandable approach - the news is always in search of a spectacle and drama. But the school system needs healing, not salt in the wound. Therefore, the role of the media should be exemplary and educational.

We can summarize that the students - the brightest part of each society - have lost their path towards each other. Maybe this is a crisis of the society itself, which brings the need to show the good example, the right approach, the better future. All the messages, used by the media, when reporting such events are unidirectional and usually do not dig deep in the problem. But they clearly indicate two things (1) the lack of coordination between and inside the responsible institutions and (2) teachers need working mechanisms against school aggression

One can observe that in the social and online media, many people tend to question the school methods for coping with aggressive students. Different opinions claim that teachers are using old techniques when it comes to class discipline and that they do not have the proper tools to handle aggressive student behavior and sometimes they reach extremes, using violence as well. Other claims focus on the lack of experience, burnout, poor school climate, poor family upbringing, etc. Both articles on the aggressive teachers' behavior stigmatize the actions of the school staff and label it as "scandalous.

Many psychologists recommend sport activities, as a prevention of aggression among adolescents. Martial arts are one of the appropriate sports that allow children not only to expend energy, but also to become more tolerant (National Network for Children, 2018). Sports activities can ease the work of teachers in imposing discipline and reducing the violent acts in class.

\section{Conclusion}

One of the first major findings in the present analysis is that there is a relatively small section in the news, dedicated to opinion articles. The majority of data is related to reports of cases of violence and aggression among students and on statistics. A larger number of opinion articles would build the image of the problem and would present different solutions to it, providing the public with more insights from the school system.

Another important aspect of the analysis is the publicity of the aggression itself. A worrying phenomenon appears to be the large video content, often uploaded by students and parents on the internet. This act, on one hand, aims to embarrass the participants and the victims in the act of violence, and on the other - aims to provoke public attention, when aired by the parents of the victims. Psychologists often alarm about the harm to the mental health of students these videos can cause.

The third highlight is related to the causes and the "one to blame" for school violence. Through the media, the problem is presented unilaterally, and its causes are rarely shown. There is a noticeable tendency to blame the school institution or the teacher - whether there is no imposed control over the situation or, on the 
contrary, were taken draconian measures. One can conclude that the focus of the public is shifted towards the school authorities and the teacher in particular.

The reviewed media content and the data it shows can bring us to the conclusion that aggression in school is spread through all students - boys and girls, in primary school and secondary school, in the capital and the regional cities. It has a constant value and is provoked by numerous factors. The non-interference on behalf of the attendees during a fight and the interest to capture the moment on a video is clearly showing that the observers do not understand the seriousness of the situation and see it as entertainment.

The educational institutions should not let such cases become the new normality and the new reality. Schools can take a good example of many Bulgarian initiatives bringing sports activities to the forefront when it comes to tackling aggression. Sport is inclusive and can be practiced in different settings. Structured and systematic programs should be adopted, encouraging all Bulgarian students to be physically active. Sport promotes discipline, devotion, tolerance and fair play - the key ingredients, needed for tackling aggression at young age.

\section{NOTES}

1. BTV, 2020. "Trend": $81 \%$ ot mladite balgari sportuvat. [In Bulgarian]. 04/05, 2021, Available on: https://btvnovinite.bg/bulgaria/trend-81-ot-mladite-balgarisportuvat.html

2. Bulgaria On Air, 2020. Nad 9000 detsa sa izvurshili prestupleniya u nas za 2019 g., Retrieved 25/05, 2020, from: https://www.bgonair.bg/a/166-kriminalno/191721-nad9000-detsa-sa-izvarshili-prestapleniya-u-nas-za-2019-g

3. Darik news, 2019. Detsa hodyat na uchilishte kato na voyna - s elektroshokovi palki, boksove i nojove. Retrieved 25/05, 2020, from: https://dariknews.bg/ novini/bylgariia/deca-hodiat-na-uchilishte-kato-na-vojna-s-elektroshokovi-palkiboksove-i-nozhove-2151570

4. Darik news, 2019. Shokirashta agresiya v uchilishte v Lovech, arestuvaha vuzpitatel. Retrieved 25/05, 2020, from: https://dariknews.bg/novini/bylgariia/ shokirashta-agresiia-v-uchilishte-v-lovech-arestuvaha-vyzpitatel-2153185

5. NOVA TV, 2019. $80 \%$ ot detsata $v$ uchilishte sa stavali jertva na agresia v klas. Retrieved 26/05, 2020, from: https://nova.bg/news/view/2019/10/10/265102/80$\%$ D0 $\%$ BE\%D1\%82-\%D0\%B4\%D0\%B5\%D1\%86\%D0\%B0\%D1\%82\%D0 \%B0-\%D0\%B2-\%D1\%83\%D1\%87\%D0\%B8\%D0\%BB $\%$ D0\%B8\%D1\%89\% D0\%B5-\%D1\%81\%D0\%B0-\%D1\%81\%D1\%82\%D0\%B0\%D0\%B2\%D0\%B 0\%D0\%BB\%D0\%B8-\%D0\%B6\%D0\%B5\%D1\%80\%D1\%82\%D0\%B2\%D0 $\%$ B0- $\%$ D0 $\%$ BD $\%$ D0 $\%$ B0- $\%$ D0\%B0\%D0\%B3\%D1\%80\%D0\%B5\%D1\%81 $\% \mathrm{D} 0 \% \mathrm{~B} 8 \% \mathrm{D} 1 \% 8 \mathrm{~F}-\% \mathrm{D} 0 \% \mathrm{~B} 2-\% \mathrm{D} 0 \% \mathrm{BA} \% \mathrm{D} 0 \% \mathrm{BB} \% \mathrm{D} 0 \% \mathrm{~B} 0 \% \mathrm{D} 1 \% 81$

6. NOVA TV, 2019. Kak uchilishte vuv Velingrad shte bori agresiata v klas? Retrieved 26/05, 2020, from: https://nova.bg/news/view/2019/09/19/263117/ $\%$ D0\%BA $\%$ D0\%B0\%D0\%BA-\%D1\%83\%D1\%87\%D0\%B8\%D0\%BB $\%$ D 0\%B8\%D1\%89\%D0\%B5-\%D0\%B2\%D1\%8A\%D0\%B2-\%D0\%B2\%D0\% 
B5\%D0\%BB $\%$ D0\%B8\%D0\%BD $\%$ D0\%B3\%D1\%80\%D0\%B0\%D0\%B4$\% \mathrm{D} 1 \% 89 \% \mathrm{D} 0 \% \mathrm{~B} 5-\% \mathrm{D} 0 \% \mathrm{~B} 1 \% \mathrm{D} 0 \% \mathrm{BE} \% \mathrm{D} 1 \% 80 \% \mathrm{D} 0 \% \mathrm{~B} 8-\% \mathrm{D} 0 \% \mathrm{~B} 0 \% \mathrm{D} 0 \% \mathrm{~B} 3$ $\% \mathrm{D} 1 \% 80 \% \mathrm{D} 0 \% \mathrm{~B} 5 \% \mathrm{D} 1 \% 81 \% \mathrm{D} 0 \% \mathrm{~B} 8 \% \mathrm{D} 1 \% 8 \mathrm{~F} \% \mathrm{D} 1 \% 82 \% \mathrm{D} 0 \% \mathrm{~B} 0-\% \mathrm{D} 0 \% \mathrm{~B} 2-$ $\% \mathrm{D} 0 \% \mathrm{BA} \% \mathrm{D} 0 \% \mathrm{BB} \% \mathrm{D} 0 \% \mathrm{~B} 0 \% \mathrm{D} 1 \% 81$

7. NOVA TV, 2019. Klip s agresiovno povedenie na uchenik sreshtu uchitel nabira skorost $\mathrm{V}$ mrejata. Retrieved 26/05, 2020, from: https://nova. $\mathrm{bg} /$ news/view/2019/06/28/255316/\%D0\%BA\%D0\%BB\%D0\%B8\%

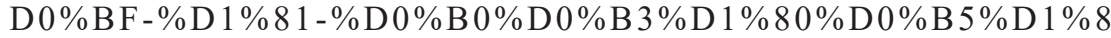
$1 \%$ D $0 \%$ B $8 \%$ D $0 \%$ B $2 \%$ D $0 \%$ BD $\%$ D $0 \%$ BE- $\%$ D $\%$ BF $\%$ D $0 \%$ BE $\%$ D $0 \%$ B $\%$ D $0 \%$ B $5 \%$ D $0 \%$ B $4 \%$ D $0 \%$ B $5 \%$ D $0 \%$ BD $\%$ D $\%$ B $8 \%$ D $0 \%$ B $5-$ $\% \mathrm{D} 0 \% \mathrm{BD} \% \mathrm{D} 0 \% \mathrm{~B} 0-\% \mathrm{D} 1 \% 83 \% \mathrm{D} 1 \% 87 \% \mathrm{D} 0 \% \mathrm{~B} 5 \% \mathrm{D} 0 \% \mathrm{BD} \% \mathrm{D} 0 \% \mathrm{~B} 8 \%$ D0\%BA-\%D1\%81\%D1\%80\%D0\%B5\%D1\%89\%D1\%83-\%D1\%83\%D1 $\% 87 \%$ D $0 \%$ B $8 \%$ D $1 \% 82 \%$ D 0\%B $5 \%$ D 0\%BB- $\%$ D $0 \%$ BD $\%$ D $0 \%$ B $0-$ $\% \mathrm{D} 0 \% \mathrm{~B} 1 \% \mathrm{D} 0 \% \mathrm{~B} 8 \% \mathrm{D} 1 \% 80 \% \mathrm{D} 0 \% \mathrm{~B} 0-\% \mathrm{D} 1 \% 81 \% \mathrm{D} 0 \% \mathrm{BA} \% \mathrm{D} 0 \% \mathrm{BE} \% \mathrm{D} 1 \% 8$ $0 \% \mathrm{D} 0 \% \mathrm{BE} \% \mathrm{D} 1 \% 81 \% \mathrm{D} 1 \% 82-\% \mathrm{D} 0 \% \mathrm{~B} 2-\% \mathrm{D} 0 \% \mathrm{BC} \% \mathrm{D} 1 \% 80 \% \mathrm{D} 0 \% \mathrm{~B} 5 \% \mathrm{D} 0 \%$ $\mathrm{B} 6 \% \mathrm{D} 0 \% \mathrm{~B} 0 \% \mathrm{D} 1 \% 82 \% \mathrm{D} 0 \% \mathrm{~B} 0 /$

8. NOVA TV, 2019. Sportat sreshtu agresiata: Yordan Yovchev s urok po fizichesko vuzpitanie $\mathrm{v}$ stolichno uchilishte. Retrieved 27/05, 2020, from: https://nova.bg/news/view/2019/04/16/247397/\%D1\%81\%D0\%BF\%D0\%BE\%D1\%80\%D1\%82\%D1\%8A\%D1\%82-\%D1\%81\%D1\%80\%D0\% B5\%D1\%89\%D1\%83-\%D0\%B0\%D0\%B3\%D1\%80\%D0\%B5\%D1\%8 $1 \%$ D0 $\%$ B $8 \%$ D $1 \% 8$ F $\%$ D $1 \% 82 \%$ D0\%B0-\%D0\%B9\%D0\%BE $\%$ D $1 \% 80$ $\%$ D0 $\%$ B $4 \%$ D0 $\%$ B $0 \%$ D0\%BD- $\%$ D0\%B9\%D0\%BE $\%$ D0\%B2\%D $\% 87$ $\%$ D0\%B5\%D0\%B2-\%D1\%81-\%D1\%83\%D1\%80\%D0\%BE\%D0\%BA$\%$ D $0 \%$ B F \% D 0 \% B E - \% D $1 \% 84 \%$ D 0 \% B $8 \%$ D $0 \%$ B $7 \%$ D $0 \%$ B 8 $\%$ D1\%87\%D0\%B5\%D1\%81\%D0\%BA\%D0\%BE-\%D0\%B2-\%D1\%81\%D1\% $82 \%$ D0 $\%$ BE $\%$ D0\%BB $\%$ D0\%B8\%D1\%87\%D0\%BD $\%$ D0\%BE- $\%$ D1\%83\%D1 $\% 87 \% \mathrm{D} 0 \% \mathrm{~B} 8 \% \mathrm{D} 0 \% \mathrm{BB} \% \mathrm{D} 0 \% \mathrm{~B} 8 \% \mathrm{D} 1 \% 89 \% \mathrm{D} 0 \% \mathrm{~B} 5 /$

9. Trud.bg, 2020. Varnenskiyat svoboden universitet shte podpomogne s resursi nad 300 uchilishta v Bulgaria. Retrieved 26/05, 2020, from: https://trud.bg/\%D0\%B2\%D0\%B0\%D1\%80\%D0\%BD $\%$ D0 $\%$ B5 $\%$ D0 $\%$ BD $\%$ D $1 \% 81 \%$ D0 $\%$ BA $\%$ D0 $\%$ B8\%D1\%8F\%D1\%82-\%D1\%81\%D0\%B2\%D0\%BE\%D0\%B1\%D0\%BE\%D $0 \%$ B $4 \%$ D0\%B5\%D0\%BD- $\%$ D1\%83\%D0\%BD $\%$ D0\%B8\%D0\%B2\%D0\%B5 $\% \mathrm{D} 1 \% 80 \% \mathrm{D} 1 \% 81 \% \mathrm{D} 0 \% \mathrm{~B} 8 \% \mathrm{D} 1 \% 82 \% \mathrm{D} 0 \% \mathrm{~B} 5 \% \mathrm{D} 1 \% 82-\% \mathrm{D} 1 \% 89 \% \mathrm{D} 0 \% \mathrm{~B} 5 /$

10. 24 Chasa, 2020. Eli i Kalin uchat mladite kak da se zashtityat ot napadateli, no bez izlishna agresia. Retrieved 26/05, 2020 from: https://www.24chasa.bg/ ojivlenie/article/8351242

11. 24 Chasa, 2020. Zashto uchilishteto stave muchenie. Retrieved 26/05, 2020 from: https://www.24chasa.bg/mnenia/article/8037341

12. Offnews, 2020. Represia ili preventsia e reshenieto za agresiata v uchilishte. Retrieved 26/05, 2020 from: https://m.offnews.bg/news/Psihologiia_18816/ Represiia-ili-preventciia-e-reshenieto-za-agresiiata-v-uchilishte 720541.html

13. News.bg (2020). Po detsa ne se plue, samo po uchiteli moje. Retrieved 26/05, 2020 from: https://news.bg/comments/po-detsa-ne-se-plyue-samo-po-uchitelimozhe.html 
14. BTV. (2020). Direktor na uchilishte v Kubrat: Publikuvaneto na klipove s agresia sred deca rajda oshte agresia. Retrieved 26/05, 2020 from: https://btvnovinite.bg/ predavania/tazi-sutrin/direktor-na-uchilishte-v-kubrat-publikuvaneto-na-klipove-sagresija-sred-deca-razhda-oshte-agresija.html

15. Actualno.com, 2019. Sluchaite na agresia v uchilishte trevojno se uvelichavat. Retrieved 26/05, 2020 from: https://www.actualno.com/education/sluchaite-naagresija-v-uchilishte-trevojno-se-uvelichavat-news 719016.html

16. Hristobotevpl.info, 2019. Evropeistiat shampion po kikboks Dimitar penchev gostuva na NU "Hristo Botev" - Pleven. Retrieved 27/05, 2020 from: https:// hristobotevpl.info/\%D0\%B5\%D0\%B2\%D1\%80\%D0\%BE $\%$ D0 $\%$ BF $\%$ D0 $\%$ B5 $\%$ D0\%B $\%$ DD $1 \% 81 \%$ D0\%BA $\%$ D0\%B8\%D1\%8F\%D1\%82-\%D1\%88\%D0\% B0\%D0\%BC $\%$ D0\%BF $\%$ D0 $\%$ B $8 \%$ D0\%BE\%D0\%BD- $\%$ D0\%BF\%D0\%BE$\%$ D0 $\%$ BA $\%$ D0 $\%$ B $8 \%$ D0 $\%$ BA $\%$ D0 $\%$ B 1\%D0\%BE $\%$ D0\%BA $\%$ D $1 \% 81-$ $\% \mathrm{D} 0 \% \mathrm{~B} 4 \% \mathrm{D} 0 \% \mathrm{~B} 8 \% \mathrm{D} 0 \% \mathrm{BC} \% \mathrm{D} 0 \% \mathrm{~B} 8 /$

\section{REFERENCES}

Ekholm,D., 2013. Sport and crime prevention: Individuality and transferability in research. Journal of Sport for Development. 1(2), 1 - 12.

Gottfried, M. A., 2009. Excused versus unexcused: How student absences in elementary school affect academic achievement. Educational Evaluation and Policy Analysis. 31(4), 392 - 415. Available from: https://doi. org/10.3102/0162373709342467

Hamlin, D. \& Li, A., 2019. The relationship between parent volunteering in school and school safety in disadvantaged urban neighborhoods. Journal of School Violence. 19(3), 362 - 376. Available from: https://doi.org/10.10 80/15388220.2019.1700801

Lee, Y. \& Lim, S., 2019. Effects of Sports Activity on Sustainable Social Environment and Juvenile Aggression. Sustainability. 11(8), 2279. Available from: https://doi.org/10.3390/su11082279

Neild, R. C. \& Balfanz, R., 2006. Unfulfilled promise: The dimensions and characteristics of Philadelphia's dropout crisis, 2000-2005. Philadelphia Youth Network. 8 - 12. Available from: https://files.eric.ed.gov/fulltext/ ED538341.pdf

Ripski, M. B. \& Gregory, A., 2009. Unfair, unsafe, and unwelcome: Do high school students' perceptions of unfairness, hostility, and victimization in school predict engagement and achievement? Journal of School Violence. 8(4), 355 - 375. Available from: https://doi. org/10.1080/15388220903132755

Spencer, A. M., 2009. School attendance patterns, unmet educational needs, and truancy: A chronological perspective. Remedial and Special Education. 30(5), 309 - 319. Available from: https://doi. org/10.1177/0741932508321017 
Trajkovic, N., et al., 2020. Reducing Aggression and Improving Physical Fitness in Adolescents Through an After-School Volleyball Program. Front. Psychol. 11. Available from https://doi.org/10.3389/fpsyg.2020.02081

UNICEF, 2018. Together against violence in schools. Retrieved 07/05. 2021, from: https://www.unicef.org/bulgaria/en/together-against-violence-schools

National Network for Children, 2019. Retrieved 07/05. 2021, from: https:// nmd.bg/

National Network for Children, 2018. Detski psiholozi preporachvat sport sreshtu agresiyata pri uchenitsite. Retrieved 07/05.2021, from: https:// nmd.bg/\%d0\%b4\%d0\%b5\%d1\%82\%d1\%81\%d0\%ba\%d0\%b8-\%d0\%bf $\% \mathrm{~d} 1 \% 81 \% \mathrm{~d} 0 \% \mathrm{~b} 8 \% \mathrm{~d} 1 \% 85 \% \mathrm{~d} 0 \% \mathrm{be} \% \mathrm{~d} 0 \% \mathrm{bb} \% \mathrm{~d} 0 \% \mathrm{be} \% \mathrm{~d} 0 \% \mathrm{~b} 7 \% \mathrm{~d} 0 \% \mathrm{~b} 8-$ $\% \mathrm{~d} 0 \%$ bf $\%$ d1\%80\%d0\%b5\%d0\%bf\%d0\%be\%d1\%80\%d1\%8a\%d1\%87 $\% \mathrm{~d} 0 \% \mathrm{~b} 2 \% \mathrm{~d} 0 \% \mathrm{~b} 0 \% \mathrm{~d} 1 \% 82-\% \mathrm{~d} 1 \% 81 \% \mathrm{~d} 0 \% \mathrm{bf} \% \mathrm{~d} 0 \% \mathrm{be} \% \mathrm{~d} 1 \% 80 \% \mathrm{~d} 1 \% 82-$ $\% \mathrm{~d} 1 \% 81 /$

Center for the study of democracy, 2020. Domashnoto nasilie nad jeni $v$ Bulgaria predi, po vreme i sled pandemiata ot COVID-19. Retrieved 01/05, 2021, from: https://csd.bg/bg/blog/blogpost/2020/07/06/domashnotonasilie-nad-zheni-v-blgarija-predi-po-vreme-i-sled-pandemijata-otcovid-19/

$\triangle$ Vera Zaharieva

https://orcid.org/0000-0002-2797-0811

National Sports Academy "Vassil Levski"

Sofia , Bulgaria

E-mail: vrzaharieva@gmail.com 